\title{
GENERAL SCIENCE IN THE STATE OF WASHINGTON.
}

By A. A. Douglass and H. Noel Bakke, State College of Washington, Pullman.

During the latter part of the school year of 1919-20 a questionnaire was sent to the high schools in the state of Washington, to learn the status of the course in general science. The following table shows the number of schools having a general science course, and compares Washington with the North Central Association':

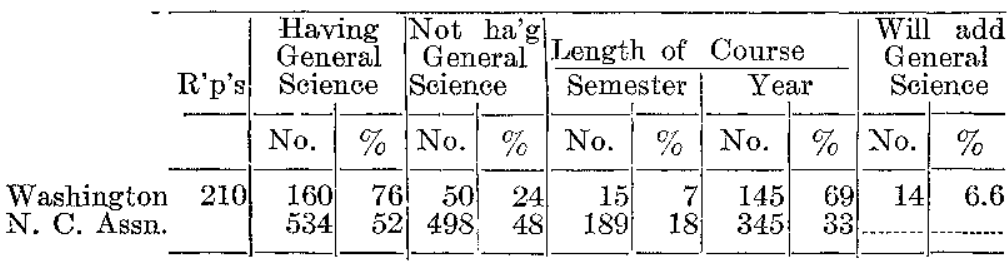

General Science is found in such a large majority of the schools of this state and is so often offered in the ninth grade that it may be regarded as one of the regular courses for high school freshmen. From the foregoing table it will be seen that in comparison with the North Central Association, as a whole, general science is much more common in Washington. Colorado, Iowa, Kansas, Nebraska and South Dakota, of the North Central Association, have general science in approximately 70 per cent of the schools reporting. The extent of general science in Washington high schools is further shown by the fact that 18.9 per cent of all the students enrolled in the high schools returning the questionnaire take the course, while 24.4 per cent are enrolled in special science courses. In 45 high schools general science is required for graduation, in 100 it is not required, and in 10 the course is necessary for graduation in science curricula. Thus it seems that the course has a great drawing power.

A tabulation of the aims and values of the course as listed by those replying to the questionnaire shows the same chaotic condition that is found elsewhere, as well as dissatisfaction with the course on the part of a considerable number. Howe $\mathrm{H}^{2}$ found the dominant purposes of general science, as listed by 80 teachers of the subject, to be "to give each pupil the greatest possible understanding, appreciation, and control of his everyday environment, to acquaint him with some of the most important industrial and social applications of science, and to furnish as wide a fund

'Bureau of Fducation, Bulletin, 1919, No. 45, p. 93.

2School Science and Mathematics, Vol. 19, pp. 248-25. 
of information about nature and science as time permits." These aims are frequently stated by Washington teachers, but that aims are not clearly defined and therefore do not control subjectmatter is indicated. Much more important, judging from the number of times mentioned, is the foundation for the later sciences and the aid in selecting subsequent special science courses which general science is supposed to give. Sixty-three per cent of those replying to the questionnaire are favorably disposed to general science, although more than half have some criticism to offer or some qualification to make. Thesc criticisms and qualifications in most cases have to do with the training of teachers, textbooks, and the presentation of the subject. Twenty-two per cent give no opinion as to the value of general science, and 15 per cent express themselves as not in favor of it, largely because of its composite nature. Thirteen additional schools have for various reasons dropped the subject.

The text is usually a fair index to the subject-matter of a course. Making use of this criterion, general science courses in Washington lack unanimity and coherent organization. The need of a definite statement of aims is again emphasized. Nine different texts are used, but none seems entirely satisfactory. Nearly 50 per cent of the schools do not follow the order of topies as given in the text used. It was thought that a correlation might exist between the "satisfactory" texts and the order

\begin{tabular}{|c|c|c|c|c|c|}
\hline & \multirow{2}{*}{$\begin{array}{l}\text { No. } \\
\text { Sehools } \\
\text { Using } \\
\text { Text }\end{array}$} & \multicolumn{2}{|c|}{$\begin{array}{l}\text { Is the Text } \\
\text { Satisfactory? }\end{array}$} & \multicolumn{2}{|c|}{$\begin{array}{l}\text { Do you follow } \\
\text { order of topies? }\end{array}$} \\
\hline & & Yes & No & Yes & No \\
\hline $\begin{array}{l}\text { Hessler } \\
\text { First Year Science }\end{array}$ & 59 & 30 & 29 & 32 & 27 \\
\hline $\begin{array}{l}\text { Caldwell and Eikenberry } \\
\text { General Science }\end{array}$ & 21 & 15 & 6 & 7 & 12 \\
\hline $\begin{array}{l}\text { Snyder } \\
\text { Everyday Science }\end{array}$ & 24 & 15 & 9 & 13 & 10 \\
\hline $\begin{array}{l}\text { Clarke } \\
\text { Introduction to Science }\end{array}$ & 12 & 8 & 4 & 7 & 4 \\
\hline $\begin{array}{l}\text { Elhuff } \\
\text { General Science }\end{array}$ & 8 & 4 & 4 & 2 & 3 \\
\hline $\begin{array}{l}\text { Lake } \\
\text { General Seience }\end{array}$ & 5 & 4 & 1 & 2 & 3 \\
\hline $\begin{array}{l}\text { Pease } \\
\text { General Science }\end{array}$ & 4 & 0 & $\ldots$ & $\cdots$ & $-\cdots-$ \\
\hline $\begin{array}{l}\text { Trafton } \\
\text { Science of the Home }\end{array}$ & 1 & 1 & $-\cdots$ & $\cdots$ & $\ldots$. \\
\hline $\begin{array}{l}\text { Sclenee of the Home } \\
\text { Van Buskirk and Smitll } \\
\text { Seience of Everyday Life }\end{array}$ & 2 & 2 & 0 & 1 & 1 \\
\hline . Totals & 136 & 79 & 53 & 64 & 60 \\
\hline
\end{tabular}


of topics followed, but examination showed no such relation to exist. The preceding table gives a summary of the textbook situation.

In many cases supplementaly texis and references are found, although 10 per cent of the teachers admit they use only the textbook. Thirty per cent mention another general science text as their chief source for reference work; 21 per cent, textbooks in physics, chemistry, physiography and other special sciences; and only 6 per cent make use of scientific bulletins and periodicals. Thirty-three per cent did not answer the question.

The amount of time devoted to laboratory work per week and the person or persons performing the experiments are shown in the following table. The periods are, with a few exceptions, 40 minutes in length.

\begin{tabular}{|c|c|c|c|c|}
\hline \multirow{2}{*}{$\begin{array}{l}\text { Number of } \\
\text { Sehools }\end{array}$} & \multirow{2}{*}{$\begin{array}{l}\text { Periods } \\
\text { per week }\end{array}$} & \multicolumn{3}{|c|}{ Experiments performed by } \\
\hline & & Pupils & 'Teacher & Both \\
\hline $\begin{array}{r}12 \\
19 \\
65 \\
5 \\
14 \\
5 \\
1 \\
3\end{array}$ & $\begin{array}{l}0 \\
1 \\
2 \\
3 \\
4 \\
5 \\
7 \\
*\end{array}$ & $\begin{array}{r}2 \\
0 \\
25 \\
2 \\
6 \\
4 \\
0 \\
0\end{array}$ & $\begin{array}{r}6 \\
10 \\
9 \\
0 \\
1 \\
0 \\
0 \\
3\end{array}$ & $\begin{array}{r}4 \\
9 \\
31 \\
3 \\
7 \\
1 \\
1 \\
0\end{array}$ \\
\hline 124 & $:$ & 39 & 29 & 56 \\
\hline
\end{tabular}

From this it seems that on the one extreme there are several schools which offer only a textbook course, while on the other there are schools which depend almost entirely upon the laboratory method of instruction. Fifty two per cent of those answering the question allow two pcriods per week for laboratory work. It is interesting to note that in only 31 per cent of the schools are the experiments performed by the pupils, while in 24 per eent the pupils have no part in the experiments and in 45 per cent they share this work with the teacher.

Seventy schools, or 44 per cent of those answering the question, purport to teach by the problem method; 25 , or 17 per cent, claim they use this method in part. Fifty-six schools, or 37 per cent, say they do not teach by the problem method. Judging from the amount of time spent in the laboratory and from the fact that only one of the texts used in this state (and that particular text by only a few schools) is written from the problem or project standpoint, it is doubtful if the meaning of "problem method" is clear. 
Very few of the Washington general science teachers have had special training. In the small high schools the course is frequently assigned to the teacher who has the time to teach it with little regard to his fitness. To the question, "Has your general science teacher had special training?" 154 answered in the negative and 11 in the affirmative. An examination of the "special training" shows that in some cases it consists of a summer course in general science or more meager training. Replies to a request for suggestions for training general science teachers show a lack of grasp of the fundamental principles underlying general science. Sixty-one gave answers to the effect that acquaintance with the various fields of special science would constitute requisite training; twenty believed that a general science course in college is necessary, and thirty-one spoke in terms of a viewpoint on the part of the teacher which would make for acquaintance with the everyday environment and social and industrial applications.

Summarizing, we may say that general science is a ninth grade subject in three-fourths of the high schools in the state of Washington, and that it is taken by nearly all of the students in the schools where it is offered. A majority of school men express their belief in the subject, although many criticisms are made. There is no unanimity as to the purposes of general science, although there is considerable agreement that it should serve as a foundation for later work in the special sciences and should aid the pupil in selecting later science courses. There is the widest diversity in the amount of time given to laboratory work, in the material included in the course, and in methods of teaching generally. General science teachers have had almost no special preparation for their work. There is the greatest need for a clear statement of the aims of general science, for subjectmatter that is intelligently organized, and for facilities to train the teachers who are to handle this work.

\section{THE BULL MOUNTAIN COAL FIELD.}

The Bull Mountain coal field, in. Musselshell County, Mont., according to an estimate made by the United States Geological Survey, contains nearly five billion tons of coal. A small part of this immense reserve of coal has already been mined, but by comparison with the total in the ground, the quantity mined is practically negligible. This coal field is described in Bulletin 646 of the Geological Survey, a copy of which may be obtained free of charge on application to the Director of the Survey at Washington. 